\title{
Case Study of an Intense Wind Event Associated with a Mesoscale Convective System in West Sumatera during the HARIMAU2006 Campaign
}

\author{
Masayuki KAWASHIMA, Yasushi FUJIYOSHI, Masayuki OHI \\ Institute of Low Temperature Science, Hokkaido University, Sapporo, Japan \\ Shuichi MORI \\ Research Institute for Global Change (RIGC), \\ Japan Agency for Marine-Earth Science and Technology (JAMSTEC), Yokosuka, Japan \\ Namiko SAKURAI \\ National Institute for Earth Disaster Prevention (NIED), Tsukuba, Japan \\ Yoshiko ABE \\ Graduate School of Environmental Earth Science, Hokkaido University, Sapporo, Japan \\ Wendi HARJUPA \\ National Institute of Aeronoutics and Space (LAPAN), Jakarta Pusat, Indonesia \\ Fadli SYAMSUDIN \\ Agency for the Assessment and Application of Technology (BPPT), Jakarta Pusat, Indonesia \\ and \\ Manabu D. YAMANAKA ${ }^{\dagger}$ \\ SATREPS-MCCOE Promotion Office, Agency for the Assessment and Application of Technology (BPPT), \\ Jakarta Pusat, Indonesia \\ (Manuscript received on 31 May 2010, in final form 21 October 2010)
}

Corresponding author: Masayuki Kawashima, Institute of Low Temperature Science, Hokkaido University, Sapporo 060-0819, Japan.

E-mail: kawasima@lowtem.hokudai.ac.jp

$\dagger$ On leave from Research Institute for Global Change

(RIGC), Japan Agency for Marine-Earth Science and Technology (JAMSTEC), and Graduate School of Science, Kobe University, Japan.

(C) 2011, Meteorological Society of Japan 


\begin{abstract}
In this study, the processes responsible for an intense wind event that occurred in west Sumatera on November 19, 2006, during the first campaign of the Hydrometeorological ARay for Isv-Monsoon AUtomonitoring (HARIMAU) were investigated.

Strong winds of $17 \mathrm{~m} \mathrm{~s}^{-1}$ and a sudden temperature drop of $5 \mathrm{~K}$ were observed at an X-band Doppler radar site associated with the passage of a convective system, and some houses were severely damaged. The convective system developed under an environment of strong low-level easterly vertical shear associated with the easterly region of an equatorial Rossby wave. The northern part of the convective system possessed qualitatively similar structures to midlatitude bow echoes, including the convex shape of the convective line, a descending rear-inflow jet positioned at its apex, and mesoscale vortices on both sides of the rear-inflow jet. The low-level wind behind the convective system formed a channel of strong easterly wind as it passed through an area of relatively low topography in the mountain range. The enhanced easterly wind was thought to contribute to the formation of the bow echo-like structure in the northern part of the convective system. This easterly rear-inflow jet was further accelerated in the convective system and descended near the leading edge, forming divergent strong winds at the surface.

The sounding data that were taken after the passage of the convective system indicated that dry air appeared in the lower troposphere associated with an enhancement of the southerly component of the wind. An analysis of objective reanalysis data suggests that the southerly was probably associated with westward-propagating mixed Rossby-gravity waves with a period of approximately 5 days. It is suggested that the dry air intruded into the convective system across the back edge of the precipitation area and caused enhanced evaporative cooling, which resulted in the effective downward transport of the enhanced easterly momentum.
\end{abstract}

\section{Introduction}

The Indonesian Maritime Continent (hereafter IMC) is located in the warm pool region where convective activities are most intense all over the world (Ramage 1968). Convections over the IMC represent a dominant heat source for atmospheric circulation and play an important role in the variability of the tropical climate and global circulation.

A diurnal cycle of convective activity is one of the dominant phenomena in the IMC. Analyses of satellite and radar data revealed that convective activity becomes intense in the mountainous region of the western part of Sumatera Island during the day, and cloud systems then migrate westward and eastward during the night (e.g. Mori et al. 2004; Sakurai et al. 2005; Kawashima et al. 2006).

Despite the frequent occurrence of active convections, the surface wind perturbations caused by diurnal convective activity are usually not strong, and the observations of damaging winds, such as those associated with midlatitude severe convective systems are rare. This is partly because the relatively moist low and mid-tropospheric environment is not conducive to the formation of evaporativelycooled strong downdrafts. However, it has been reported that strong winds from the mountains sometimes appear in the coastal area of west Sumatera and cause severe damage to houses or capsize fishing boats.
Relatively strong $\left(\sim 10 \mathrm{~m} \mathrm{~s}^{-1}\right)$, persistent surface winds observed over the IMC are generally associated with westerly wind bursts (WWBs; Wyrtki 1975; Kiladis et al. 1994; Murakami and Sumathipala 1989; Nitta and Motoki 1987), which have a 1- to 3-week duration and are potentially important in triggering and sustaining El Niño-Southern Oscillation (ENSO) events. Previous studies indicate, however, that deep convections are inhibited during periods of WWBs. From a case study during the Tropical-Ocean Global-Atmosphere Coupled Ocean-Atmosphere Response Experiment (TOGACOARE), Lin and Johnson (1996) showed that a low sea surface temperature and large tropospheric vertical shear inhibited the development of deep convection during WWBs. Murata et al. (2006) showed that an intensification of westerly wind that is accompanied by a super cloud cluster can cause a dry-air intrusion from the Indian Ocean to Sumatera in the lower and middle troposphere and suggested that the dry air plays a role in suppressing convective activity over Sumatera. Seto et al. (2004) and Seto et al. (2006) also reported that the Sumatera region became convectively inactive after an intensification of lower-tropospheric westerly wind. These results suggest that the local enhancement of the large westerly momentum by convections seldom occurs during WWBs.

The Hydrometeorological ARay for IsvMonsoon AUtomonitoring (HARIMAU), a 5- 
year project under the Japan EOS Promotion Program (JEPP), has been operating since 2005 to set up a radar-profiler network over the IMC (Yamanaka et al. 2008). The first intensive observation campaign was conducted in west Sumatera from October 26 to November 27, 2006 (HARIMAU2006) using two X-band Doppler radars (XDRs) that covered the sea area off the west coast of Sumatera Island, rawin sondes, and Equatorial Atmospheric Radar (EAR).

During the campaign, a diurnal cycle of convective activity occurred almost every day, and westward migrations of cloud systems were commonly observed in central Sumatera (Mori et al. 2011). On November 19, 2006, strong southeasterly gust winds of $17 \mathrm{~m} \mathrm{~s}^{-1}$ and a sudden temperature drop of $5 \mathrm{~K}$ was observed at an XDR site associated with the passage of an westward-migrating convective system. The intense wind caused severe damage to some houses around the XDR site (Fig. 1).

In this study, we describe the intense wind event and investigate the mechanisms responsible for the intense wind by using data obtained during the HARIMAU2006 campaign. This paper is organized as follows. A description of the data used in this study is given in section 2. Section 3 describes the evolution of synoptic environment during the HARIMAU2006 campaign. The surface signatures of the intense wind and radar overview are given in sections 4 and 5, respectively. Section 6 provides the Doppler radar analysis of the structure and the evolution of a convective system that caused the in-

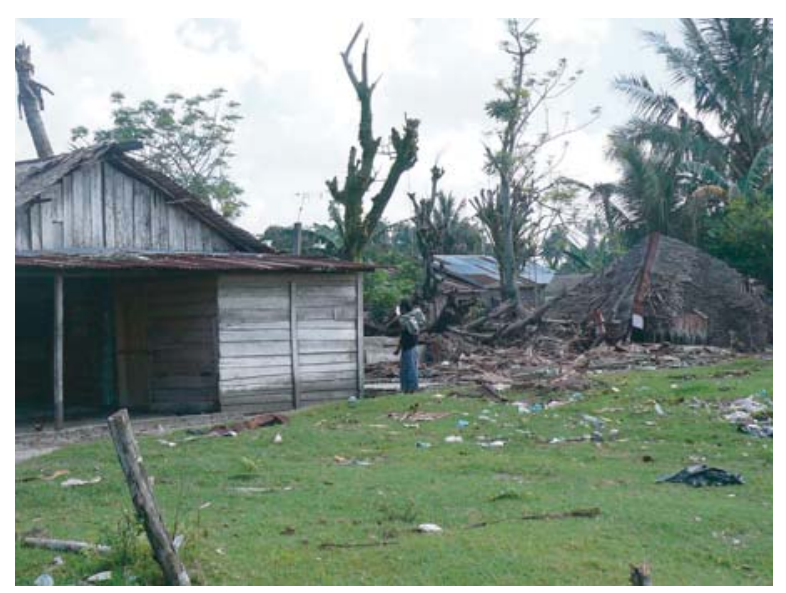

Fig. 1. Photograph of a house near the Tiku XDR site that was destroyed by intense wind on November 19, 2006. tense winds. Section 7 discusses the factors responsible for the occurrence of intense winds. A summary and conclusions are presented in section 8 .

\section{Data}

\subsection{Doppler radar}

The main data analyzed in this study were obtained by the XDR systems of the Institute of Low Temperature Science (ILTS), Hokkaido University, and the Japan Agency of Marine-Earth Science and Technology (JAMSTEC). Figure 2 shows the XDR sites, the radar detection range, and the topographic map of the observation area. The ILTS XDR was installed at Tiku Beach, $\left(99.92^{\circ} \mathrm{E}\right.$, $0.40^{\circ} \mathrm{S}, 3 \mathrm{~m}$ above mean sea level (ASL)), and the JAMSTEC-XDR was installed at the Minangkabau International Airport (MIA) of Padang $\left(100.30^{\circ} \mathrm{E}, 0.79^{\circ} \mathrm{S}, 5 \mathrm{~m} \mathrm{ASL}\right)$. The XDRs collected three-dimensional reflectivity and Doppler velocity data every $6 \mathrm{~min}$ over an $83-\mathrm{km}$ radius, through a series of conical scans with antenna elevation angles from $0.5^{\circ}$ to $50^{\circ}$.

Reflectivity and Doppler velocity data were interpolated on a Cartesian coordinate system with a $1.0-\mathrm{km}$ and $0.5-\mathrm{km}$ grid spacing in the horizontal and vertical direction, respectively, using a Cressman weighting function (Cressman 1959). The shape of the influence volume for the interpolation was a spheroid whose horizontal and vertical semiaxes were $1.0 \mathrm{~km}$ and $0.5 \mathrm{~km}$, respectively.

The unfolding of the Doppler velocity data was performed following the method of Yamada and Chong (1999). The synthesis of two XDR data sets was performed using the multi-Doppler synthesis and continuity adjustment technique (MUSCAT) described by Bousquet and Chong (1998) and Chong and Cosma (2000). Vertical winds were calculated by integrating the anelastic mass continuity equation upward, assuming that the vertical wind vanishes at the surface. These vertical winds were subject to variational adjustments using a floating boundary condition concept (Chong and Testud 1983) when necessary. An advantage of the floating boundary condition concept is that it does not require upper boundary conditions of vertical winds, which are not always easy to assume.

\subsection{Rawinsonde}

Intense rawinsonde observations were carried out at the Tabing station $\left(100.35^{\circ} \mathrm{E}, 0.88^{\circ} \mathrm{S}\right)$ of the Indonesian Meteorological and Geophysics Agency (BMG; now the Indonesian Meteorological Clima- 

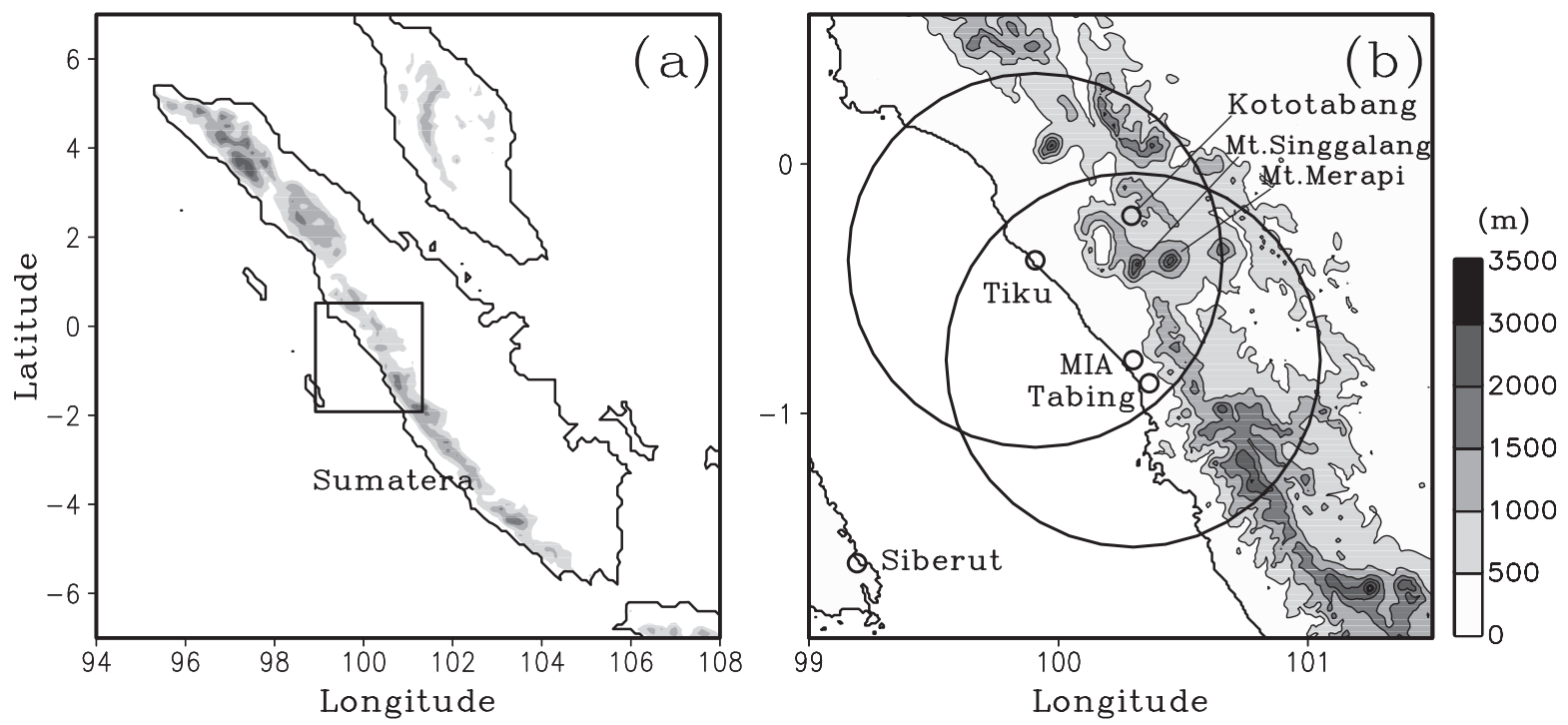

Fig. 2. (a) Surface topography of Sumatera Island in the western part of the Indonesian Maritime Continent (IMC). (b) A detailed topography and the locations of observation stations in the square area in panel (a). Circles indicate the observational ranges of XDRs located at MIA and Tiku.

tological and Geophysics Agency, BMKG) for 33 days (from October 26 to November 27, 2006) and at Siberut (Siberut National Park Office) $\left(99.20^{\circ} \mathrm{E}\right.$, $1.58^{\circ} \mathrm{S}$ ) for 11 days (November 4-14, 2006). The time interval of the observation was 6 hours. On November 10, 2006, data were obtained every 3 hours. The rawinsonde data at Tabing, edited every $100 \mathrm{~m}$ in the vertical direction, were used in the present study.

\subsection{Surface data}

Surface data were obtained every minute at MIA, Tiku, Tabing, Siberut and Kototabang using automatic weather stations (AWS) during HARIMAU2006. The data observed at MIA and Tiku were used in the present study.

\subsection{NCEP reanalysis}

NCEP/NCAR (National Center for Environmental Prediction/National Center for Atmospheric Research) reanalysis I (hereafter NCEP reanalysis) was used to investigate the large and synoptic-scale structures of the atmosphere. The time and horizontal resolutions of NCEP reanalysis are 6 hours and $2.5^{\circ} \times 2.5^{\circ}$, respectively.

\section{Environmental characteristics}

The time-height cross sections of zonal and meridional wind, derived from the rawinsonde observations taken at Tabing from November 7-26, 2006, are shown in Fig. 3. The time at which the intense wind was observed at the Tiku site (2215 LST on November 19; LST $=$ UTC +7 hours) is indicated by a vertical line in each figure.

During the observation period, a variation period of approximately 12 days was evident in the zonal wind speed in both the lower and upper tropospheres. The easterly wind was strong in the upper troposphere for the period November 12-17. On the other hand, the easterly was strong in the lower troposphere for the period November 15-21. The strongest easterly wind, at $700 \mathrm{hPa}$ over central Sumatera in 2006, was identified in this period in the NCEP/NCAR reanalysis data (not shown). As discussed by Yoneyama et al. (2008) and Miura et al. (2009), these strong easterly winds were associated with an easterly phase of a westward-propagating $n=1$ equatorial Rossby wave, where $n$ is the number of nodes in the meridional velocity profile.

Because an $n=1$ equatorial Rossby wave is symmetric about the equator, the 12-day variation period was not clearly seen in the meridional wind field. Rather, an approximately 5-day variation period was significant in the lower troposphere for the time period of November 15-25. The intense wind was observed at the Tiku site when the lowertropospheric easterly above the boundary layer was strongest and the southerly wind component appeared in the soundings. 

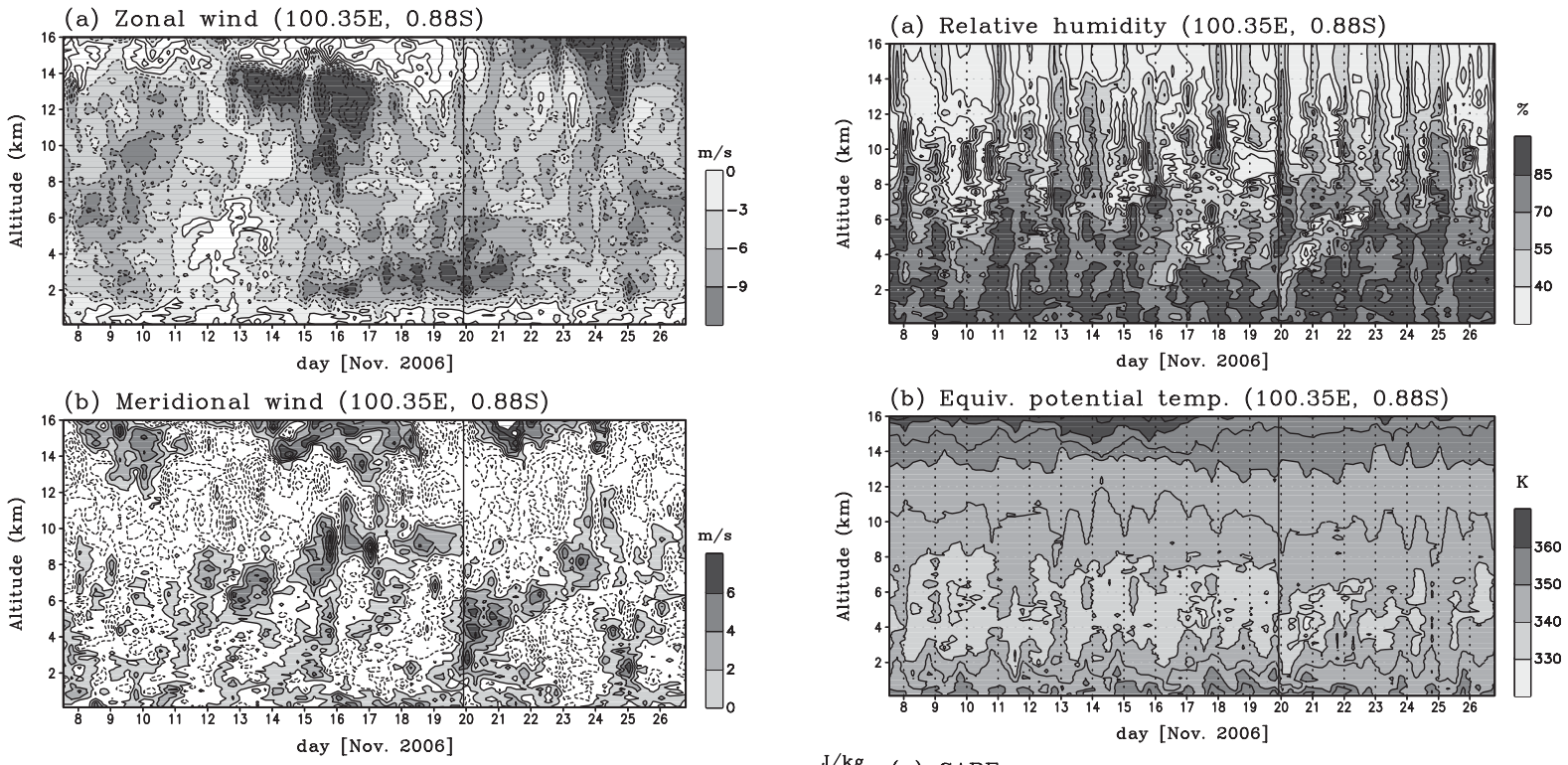

Fig. 3. Time-height distributions of (a) zonal wind speed and (b) meridional wind speed derived from the upper-air sounding launched at Tabing 4 times per day. The contour intervals are $3 \mathrm{~m} \mathrm{~s}^{-1}$ and $2 \mathrm{~m} \mathrm{~s}^{-1}$ for the zonal and meridional winds, respectively. Easterly and southerly winds are shaded in panels (a) and (b), respectively. The vertical line on each panel indicates the time at which intense surface wind was observed at the Tiku site (2215 LST on November 19, 2006).

Figure 4 shows time-height sections of relative humidity and equivalent potential temperature, and convective available potential energy (CAPE) averaged for the layer between the surface and $0.5 \mathrm{~km}$ ASL for the same period as in Fig. 3. The relative humidity (Fig. 4a) was generally higher than $70 \%$ below $6 \mathrm{~km}$ ASL during this period. However, dry air with relative humidity less than $50 \%$ was observed in the lower troposphere for the periods of November 16-18 and November 20-22. The thickness of the dry layer was approximately $2 \mathrm{~km}$, and the height of the dry layer increased with time. A comparison between Fig. $3 \mathrm{~b}$ and Fig. $4 \mathrm{a}$ indicates that the dry layer appeared associated with the lower tropospheric southerly, suggesting that the southerly wind advected dry air from the subtropics. The equivalent potential temperature showed significant diurnal variation throughout the period. The equivalent potential temperature was also low in the dry regions $(\leq 335 \mathrm{~K})$. Almost every

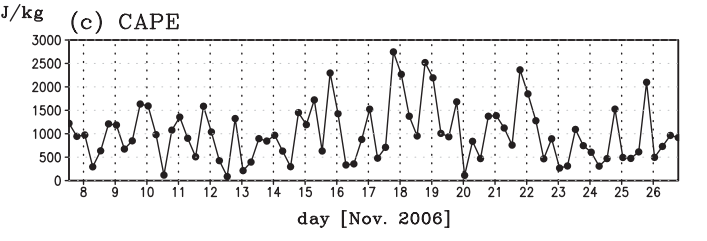

Fig. 4. Time-height distributions of (a) relative humidity, (b) equivalent potential temperature, and (c) time variation of convective available potential energy (CAPE) averaged for the layer between the surface and $0.5 \mathrm{~km}$ ASL.

day, the CAPE value for the sounding was largest at 1900 LST. The CAPE value for the sounding launched immediately before the intense wind event (1900 LST on November 19) was $1680 \mathrm{~J} \mathrm{~kg}^{-1}$, which is close to the average CAPE value at 1900 LST during the observation period (approximately $1500 \mathrm{~J} \mathrm{~kg}^{-1}$ ).

\section{Surface observations}

Figure 5 shows the time series of the wind speeds observed at the Tiku and and MIA stations. Significant diurnal variations were observed during the HARIMAU2006 campaign at the MIA and Tiku sites. The wind speed was generally less than $7 \mathrm{~m} \mathrm{~s}^{-1}$ at the Tiku site (Fig. 5a). However, a spike-like signal of strong wind, reaching $17 \mathrm{~m} \mathrm{~s}^{-1}$, was observed at 22 LST on November 19. The absence of a strong wind signal at the MIA station indicates that the strong wind event was a local phenomenon. Figure 6 shows a series of meteoro- 

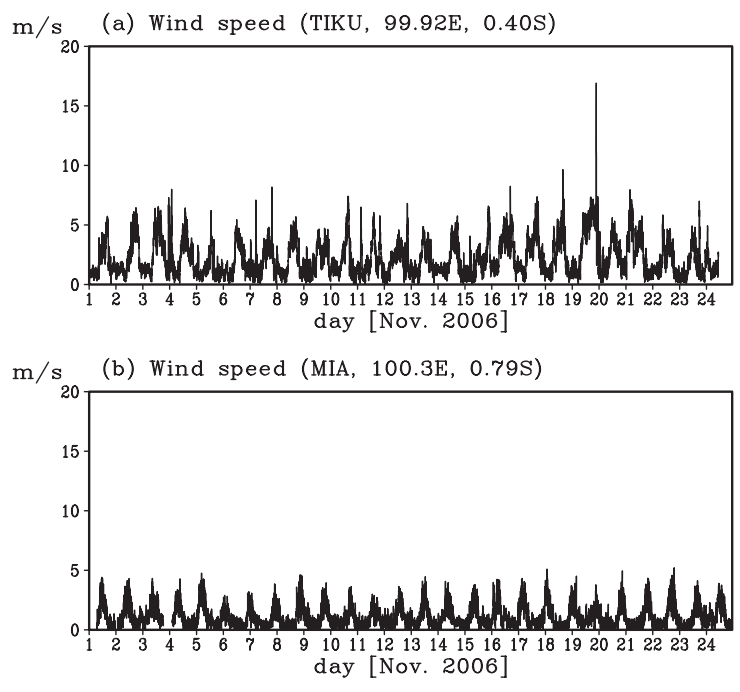

Fig. 5. Surface winds at (a) Tiku and (b) MIA, observed by AWS for the period November 1-24, 2006.

logical parameters at the Tiku site from 2150 LST to 2250 LST on November 19. From 2210 to 2215 LST, the wind speed increased from 7 to $17 \mathrm{~m} \mathrm{~s}^{-1}$ and the wind direction changed from the south to the southeast. Just after the onset of the wind gust, the temperature dropped $3 \mathrm{~K}$ in a few minutes, and then dropped $2 \mathrm{~K}$ in the following 20 minutes. The magnitudes of temperature drops that were observed associated with the passage of precipitating systems on other days during the HARIMAU2006 were $2 \sim 3 \mathrm{~K}$ at most (not shown). The relative humidity showed a sudden drop of $\sim 10 \%$ that was associated with the increase in the wind speed; it then increased to $\sim 90 \%$. The surface pressure showed a rise and fall in a very short period of time (from 2210 to 2215 LST) just before the temperature drop, suggesting that this short period variation in pressure was induced dynamically. Then, the pressure rose approximately $0.8 \mathrm{hPa}$ from 2215 to 2220 LST. Surface precipitation of $36 \mathrm{~mm} \mathrm{~h}^{-1}$ was observed at 2217 LST, a few minutes after the onset of the strong wind, after which time relatively light precipitations persisted.

\section{Radar overview}

The XDR observation indicates that the changes in various meteorological variables in Fig. 6 were caused by the passage of a mesoscale convective system. Figure 7 shows a time series of radar reflectivity at $2.0 \mathrm{~km}$ ASL from 2100 to 2230 LST. Here-

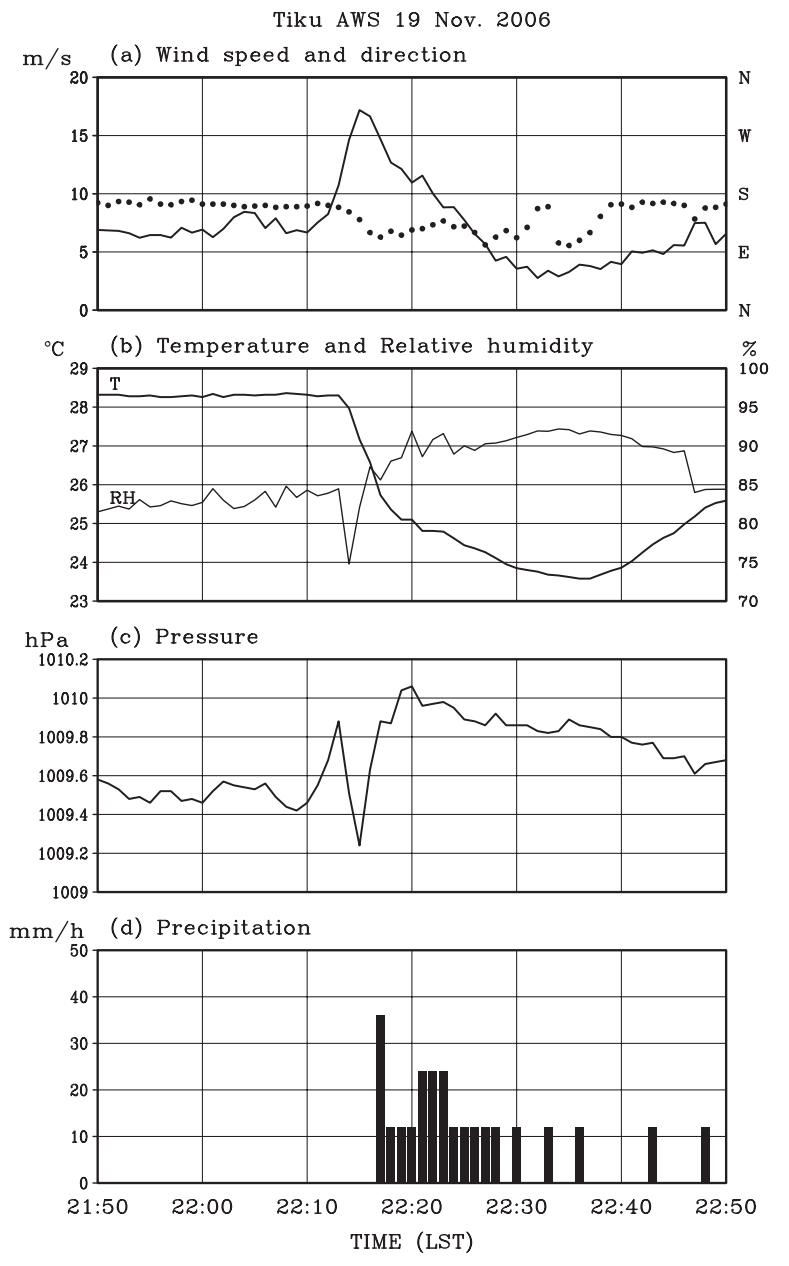

Fig. 6. Time series of meteorological parameters observed at the ground at Tiku from 2150 to 2250 LST on November 19, 2006.

after, east-west and north-south distances $(\mathrm{km})$ from the MIA radar are denoted as $x$ and $y$, respectively. Precipitation areas first appeared on radar images as isolated convective cells distributed along the mountain range (not shown). These cells then formed some groups of convective cells that were aligned roughly in the north-south direction by 2100 LST (Fig. 7a). Convective cells in the center group $(y=-15 \sim 40 \mathrm{~km}$ at $2100 \mathrm{LST})$ developed further, and the group of convective cells began to move westward by successively creating new convective cells ahead of mature cells. The formation of new convective cells is clearly indicated at $y=5 \sim 25 \mathrm{~km}, x=-10 \sim 0 \mathrm{~km}$ at 2130 LST (Fig. 7b). The group of convective cells evolved into an approximately $60 \mathrm{~km}$-long convective sys- 

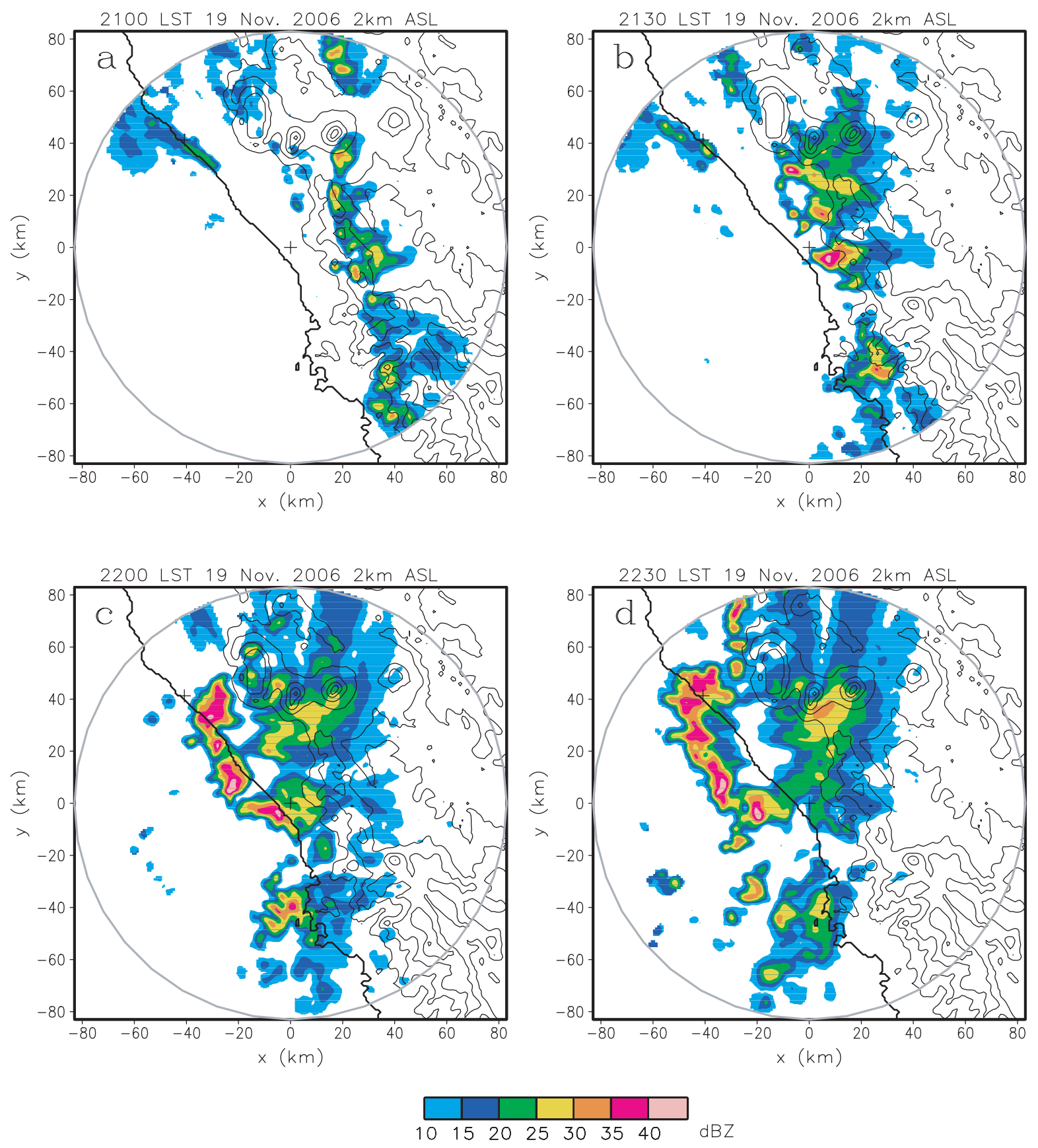

Fig. 7. Horizontal distribution of radar reflectivity (dBZ, shaded) at $2.0 \mathrm{~km} \mathrm{ASL}$, superimposed on the topography (500 m contour interval) at (a) 2100 LST, (b) 2130 LST, (c) 2200 LST and (d) 2230 LST on November 19, 2006. The locations of the Tiku and MIA XDR sites are indicated by crosses. The reflectivity scale is shown at the bottom of the figure. A gray circle indicates the observational range of MIA XDR.

tem composed of several areas of high reflectivity by 2200 LST (Fig. 7c). Between 2200 and 2230 LST, the leading edge of the northern part of the convective system passed over the Tiku site, which is consistent with the surface observation of precipitation shown in Fig. 6d. The mean motion of the convective system beyond 2200 LST estimated from the sequence of radar reflectivity maps, was 

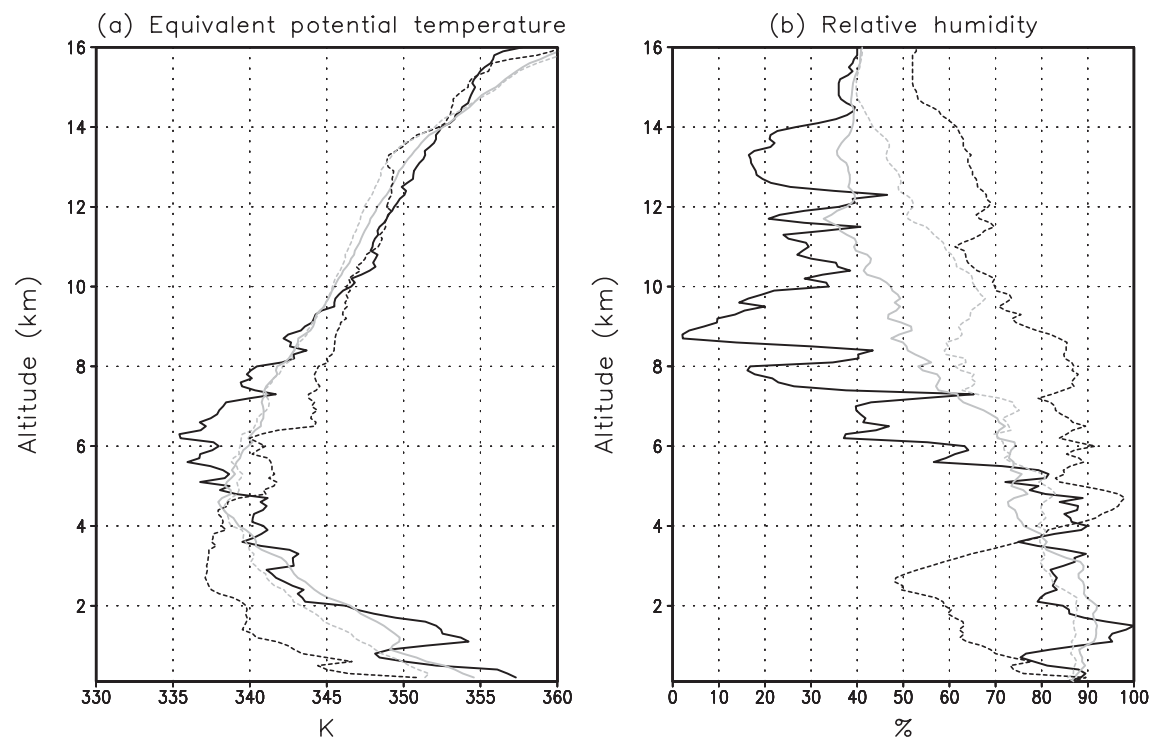

Fig. 8. Vertical profiles of (a) equivalent potential temperature $\theta_{e}$ and (b) relative humidity, deduced from radiosoundings at Tabing before (1900 LST on November 19, 2006, solid) and after (0100 LST on November 20,2006 , dashed) the passage of the convective system. The average $\theta_{e}$ and relative humidity profiles for 1900 LST (gray, solid) and 0100 LST (gray, dashed) during the HARIMAU2006 campaign are also shown.

toward the west-northwest (about 290 ) at $10.5 \mathrm{~m} \mathrm{~s}^{-1}$.

To compare the state of the atmosphere before and after the passage of the convective system, the soundings released at Tabing at 1900 LST on November 19 and at 0100 LST on November 20, which represent the prestorm and poststorm conditions, respectively, were compared (Fig. 8). For comparison, $\theta_{e}$ and relative humidity profiles for 1900 and 0100 LST, averaged for the HARIMAU2006 campaign, are also indicated by gray lines. At 1900 LST on November 19, the $\theta_{e}$ profile exhibited convective instability (i.e., $\partial \theta_{e} / \partial z<0$ ) in the layer below $6 \mathrm{~km}$ ASL. The equivalent potential temperature had a maximum value $(357 \mathrm{~K})$ at the surface and a minimum value $(335 \mathrm{~K})$ at $6.2 \mathrm{~km}$. The profile of relative humidity indicated the presence of relatively dry air above $5 \mathrm{~km}$. The level of free convection for the surface air parcels was $1 \mathrm{~km}$ ASL, and the level of neutral buoyancy was $16 \mathrm{~km}$ ASL. The $0^{\circ} \mathrm{C}$ level was located at $4.8 \mathrm{~km}$ ASL.

The comparison of average profiles of $\theta_{e}$ and relative humidity indicates that $\theta_{e}$ and relative humidity were lower in the lower troposphere, whereas relative humidity was higher in the upper troposphere at 0100 LST than at 1900 LST. This indi- cates that an overturning between potentially warm boundary layer air and potentially cold midtropospheric air was accomplished through vertical motions that were associated with convections that develop at night. The decrease of $\theta_{e}$ in the lower troposphere and the drying and moistening in the lower and upper troposphere, respectively, also occurred on November 19 associated with the passage of the convective system. However, the decreases in $\theta_{e}$ and the relative humidity in the lower troposphere were much larger than those found in the average profiles.

Figure 9 presents the zonal and meridional wind profiles. As mentioned earlier, an easterly wind prevailed throughout the troposphere, with strong vertical shear below $2 \mathrm{~km}$ ASL. Prestorm sounding indicates that the relative zonal wind was entering the system from the west at most levels except between 2 and $3 \mathrm{~km} \mathrm{ASL}$, with an intense inflow of potentially warm boundary layer air (between 0 and $2 \mathrm{~km}$ ). The poststorm sounding indicates an enhancement of the easterly in the lower troposphere except at levels below $0.5 \mathrm{~km}$ ASL. The wind speed between 1.7 and $5 \mathrm{~km}$ ASL was faster than the movement of the convective system, indicating that the dry environmental air was entering the system across the back edge of the precipitation area. 

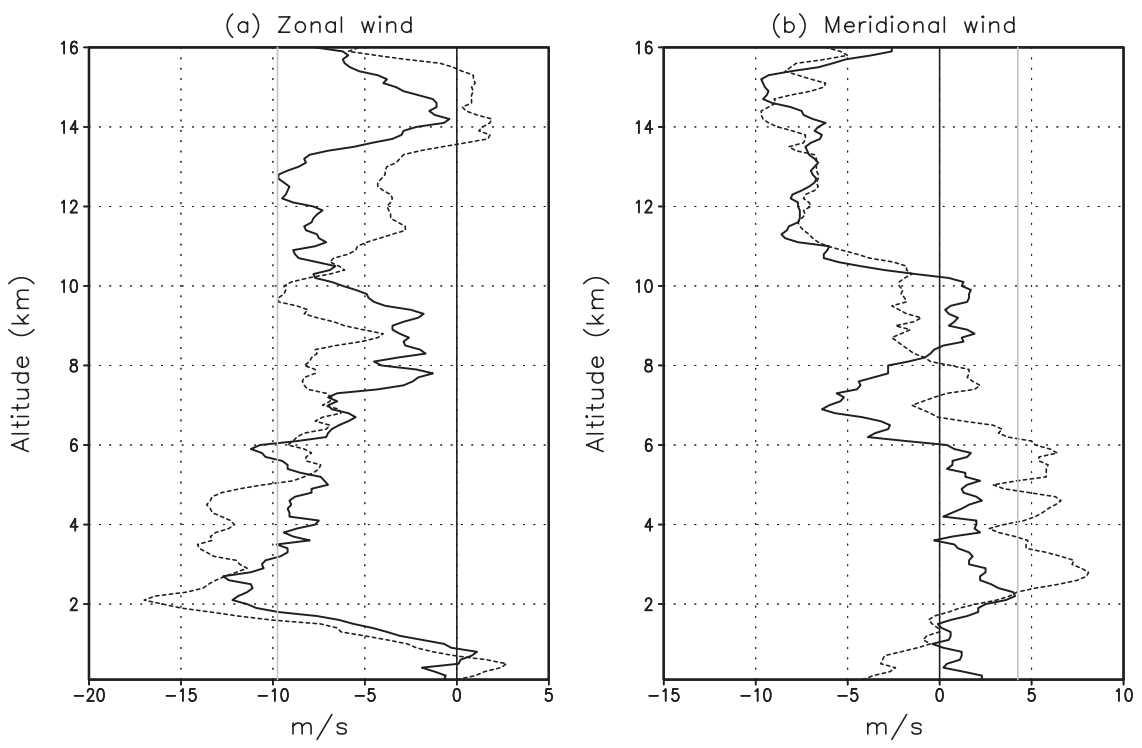

Fig. 9. Vertical profiles of (a) zonal wind speed and (b) meridional wind speed, deduced from radiosoundings at Tabing before (1900 LST on November 19, 2006, solid) and after (0100 LST on November 20, 2006, dashed) the passage of the convective system. The propagation speeds of the convective system $\left(9.8 \mathrm{~m} \mathrm{~s}^{-1}\right.$ westward, $3.8 \mathrm{~m} \mathrm{~s}^{-1}$ northward) are indicated by gray vertical lines.

The lower-tropospheric meridional wind speed in the prestorm environment was relatively weak (below $5 \mathrm{~m} \mathrm{~s}^{-1}$ ) compared with the zonal wind. However, the poststorm sounding indicated an enhanced southerly between 2 and $7 \mathrm{~km}$ ASL, which corresponds to the southerly wind noted in Fig. $3 b$. The role of this southerly wind will be discussed in section 7.

\section{Internal structure of mesoscale convective system}

In this section, the structure and evolution of the convective system that caused intense surface winds at the Tiku XDR site are described in detail.

\subsection{Horizontal structure}

Figure 10 presents a series of horizontal cross sections that show the system-relative wind vectors with radar reflectivity and the ground-relative wind vectors and horizontal wind speed (i.e., $\left(u^{2}+v^{2}\right)^{1 / 2}$ ) at $1.0 \mathrm{~km}$ ASL. At $2142 \mathrm{LST}$, convections were loosely organized, and convergence of relative winds was evident in the convective system (Fig. 10a). The ground-relative horizontal velocity field (Fig. 10d) showed a strong easterly wind greater than $18 \mathrm{~m} \mathrm{~s}^{-1}$ on the southern side of a high mountain (Mt. Singgalang, $2877 \mathrm{~m}$, located at $(x, y) \sim$
$(2 \mathrm{~km}, 42 \mathrm{~km}))$, where relatively low terrain with an elevation of approximately $900 \mathrm{~m}$ forms a gap in the mountain range $((x, y) \sim(10 \mathrm{~km}, 34 \mathrm{~km})$, see also Fig. 2b).

At 2218 LST (Fig. 10b), the divergence of horizontal winds was evident behind the leading edge of the northern part of the system $(y \sim 40 \mathrm{~km})$. Because the Tiku site is located immediately ahead of the leading edge of the precipitation area at this time, the strong gust wind observed at the Tiku XDR site can be attributed to the southeasterly divergent flow from the convective system. In the ground-relative wind field (Fig. 10e), a channel of strong horizontal wind that extended westward from the low topography area in the mountain range became evident. This flow pattern suggests that the relatively low topography allowed for the channeling of a low-level easterly across the mountain range. This point will be detailed in the next section. On the other hand, the wind was considerably weak in the downstream region of Mt. Singgalang.

The low-level southeasterly in the northern part of the convective system intensified and expanded as time elapsed. At 2248 LST, the northern part of the system was dominated by a strong wind exceeding $15 \mathrm{~m} \mathrm{~s}^{-1}$ (Fig. 10f). At this time, a channel of 

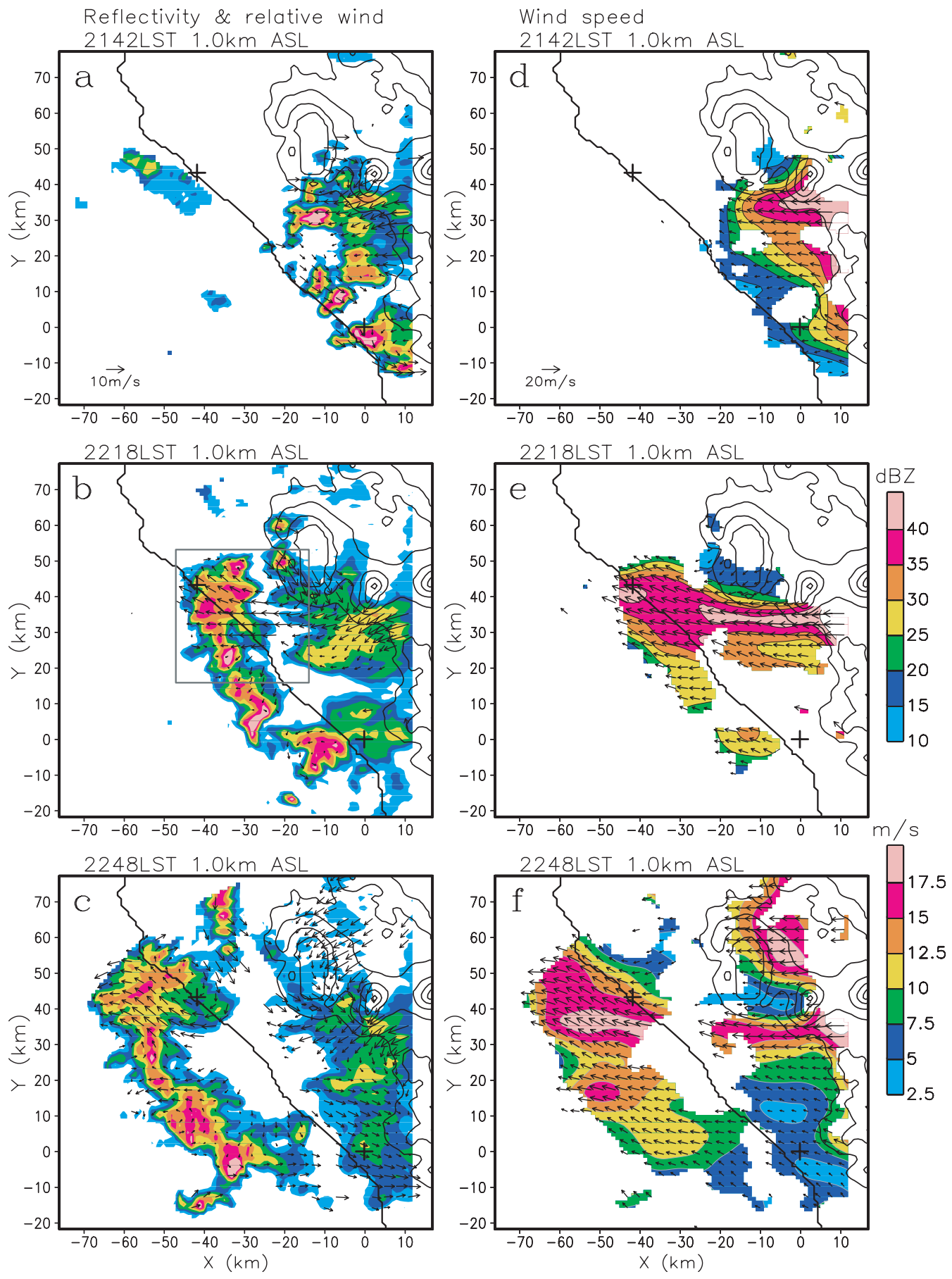

Fig. 10. Horizontal cross sections showing (left) radar reflectivity and system-relative wind vectors and (right) ground-relative wind vectors and wind speed at $1.0 \mathrm{~km}$ ASL for (a),(d) 2142 LST (b),(e) 2218 LST and (c),(f) 2248 LST on November 19, 2006. The $10 \mathrm{~m} \mathrm{~s}^{-1}$ and $20 \mathrm{~m} \mathrm{~s}^{-1}$ scaling vectors for the winds are shown in panels (a) and (d), respectively. The reflectivity and the velocity scales are shown to the right of panels (e) and (f), respectively. The locations of the Tiku and MIA XDR sites are indicated by crosses. The box in panel (b) indicates the domain shown in Fig. 11. 

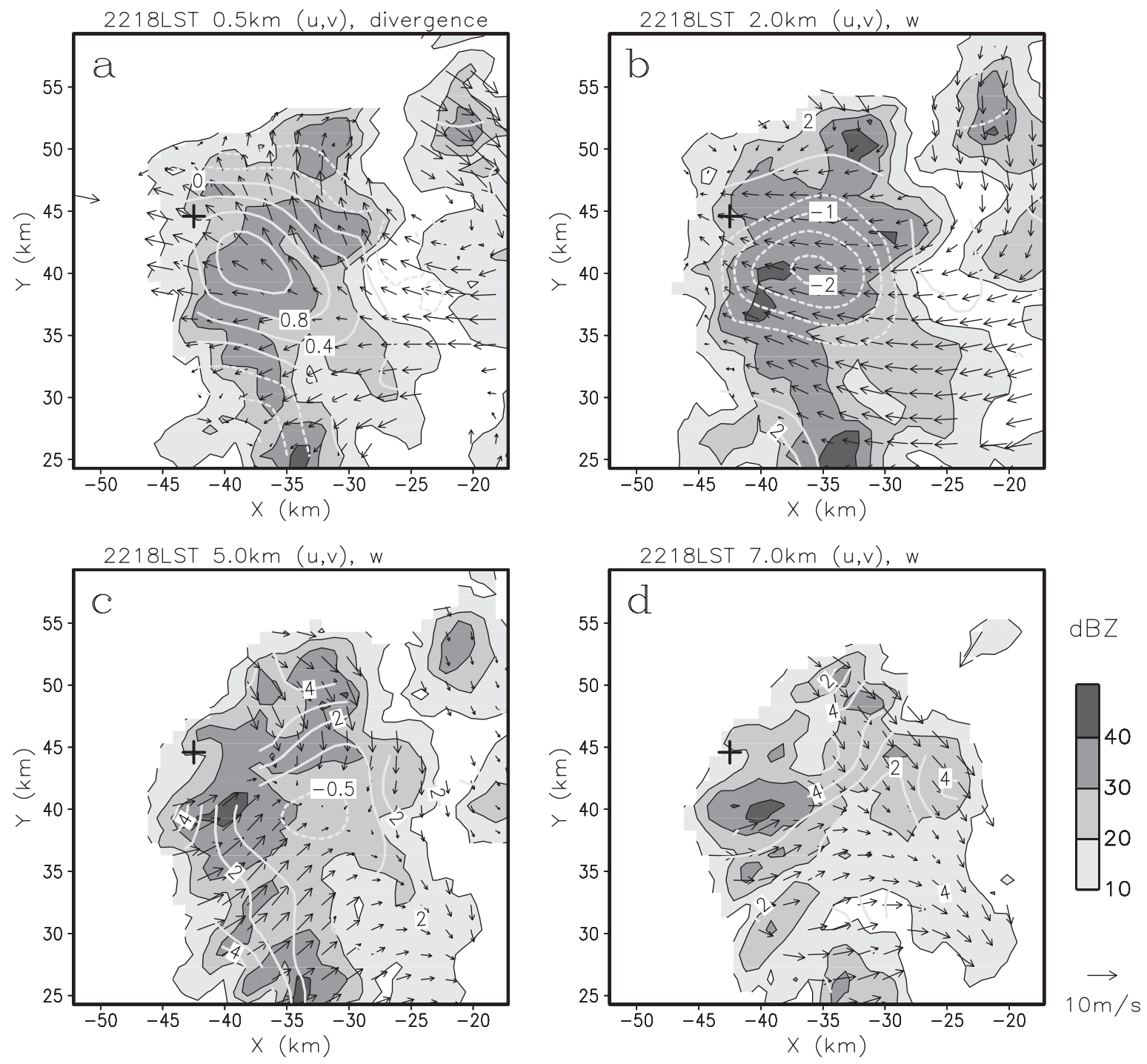

Fig. 11. Horizontal cross sections showing system-relative wind vectors and reflectivity at 2218 LST on November 19, 2006 at (a) 0.5, (b) 2.0, (c) 5.0 and (d) $7.0 \mathrm{~km}$ ASL. Contours of horizontal divergence $\left(0.4 \times 10^{-3} \mathrm{~s}^{-1}\right.$ interval $)$ are superposed on panel (a), whereas contours of vertical velocity $\left(0.5 \mathrm{~m} \mathrm{~s}^{-1}\right.$ interval for negative values and $1 \mathrm{~m} \mathrm{~s}^{-1}$ interval for positive values) are imposed on panels (b)-(d). The reflectivity scale and the $10 \mathrm{~m} \mathrm{~s}^{-1}$ scaling vector for the winds are shown to the right of panel (d). The locations of the Tiku XDR site is indicated by a cross.

weak echo became apparent at $(x, y)=(-48 \mathrm{~km}$, $33 \mathrm{~km}$ ) along the axis of rear-inflow jet. This feature resembles the rear-inflow notch that often signifies the location of a strong rear-inflow jet in midlatitude squall lines or bow echoes (e.g., Smull and Houze 1985; Smull and Houze 1987; Przybylinski 1995).

Figure 11 depicts reflectivity and system-relative wind vectors at 2218 LST for various levels for the boxed region in Fig. 10b. At $0.5 \mathrm{~km} \mathrm{ASL}$, the horizontal divergence exceeding $1.2 \times 10^{-3} \mathrm{~s}^{-1}$ was analyzed in the high-reflectivity core (Fig. 11a). The rear-inflow jet became most intense at $2.0 \mathrm{~km}$ (Fig. 11b). A mesoscale downdraft with a magnitude of up to $2 \mathrm{~m} \mathrm{~s}^{-1}$ was analyzed behind the leading edge, indicating that the rear-inflow jet descended as it approached the leading edge of the system. The cross sections at 5.0 and $7.0 \mathrm{~km}$ ASL showed 

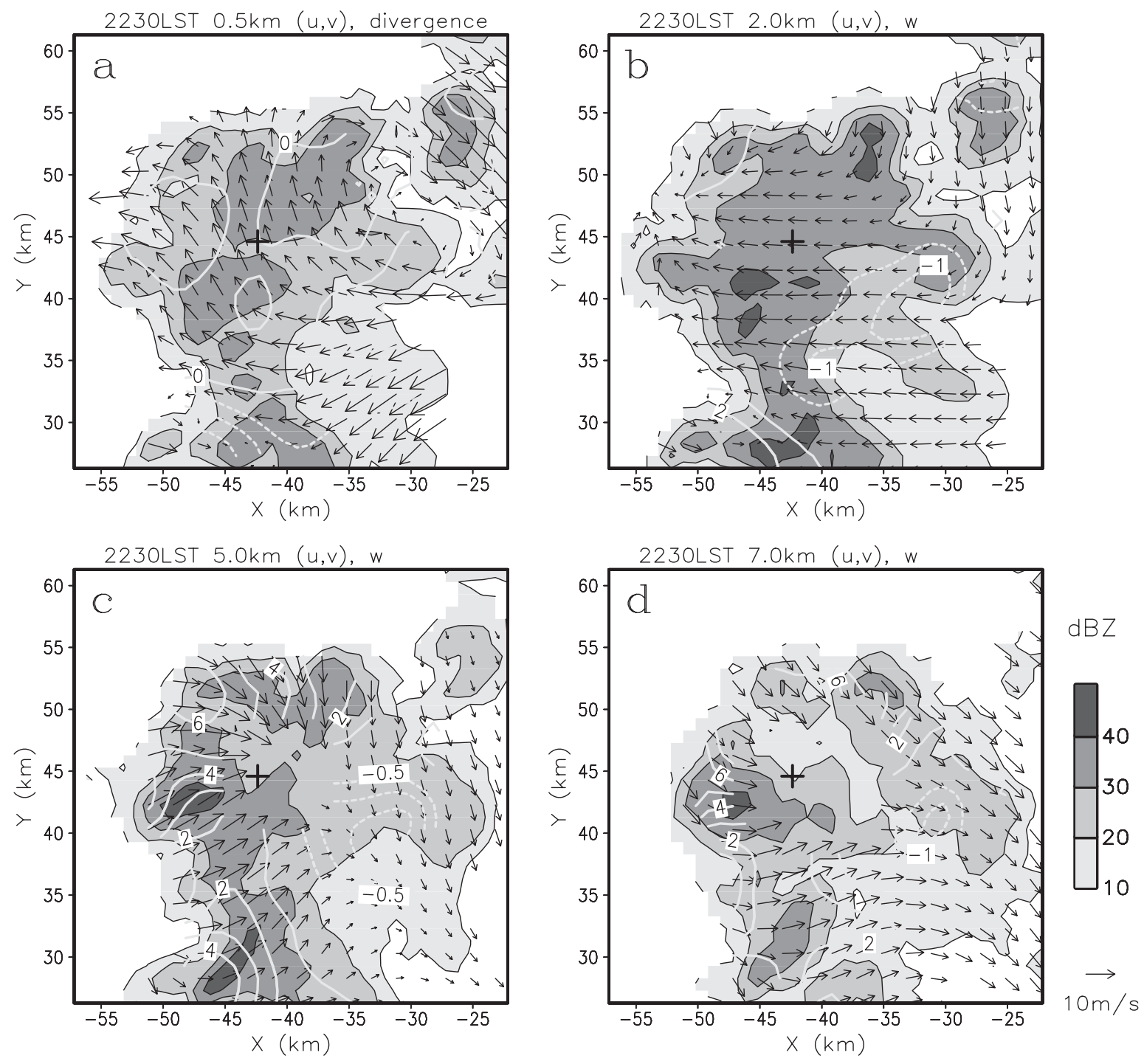

Fig. 12. Same as Fig. 11 except for 2230 LST on 19 November, 2006.

relative north-northwesterly and southwesterly flows, between which relatively weak horizontal winds were indicated. The flow pattern resembled those observed downwind of an obstacle. The northwestern portion of the precipitation echo at this level lacked velocity data, because the region was located immediately above the Tiku radar. However, the flow pattern suggested that a strong convective updraft was probably located at the northwestern part of the high reflectivity area and prestorm midlevel flows turned around the updraft.

Figure 12 depicts the same variables as in Fig. 11 but for $2230 \mathrm{LST}$. At $0.5 \mathrm{~km}$ ASL (Fig. 12a), the divergence of horizontal wind behind the leading edge became less clear and stronger wind prevailed in the high reflectivity area compared with Fig. 11a. By this time, anticyclonic and cyclonic vortical circulations were apparent in the system-relative winds on the eastern and western sides of the highreflectivity area. This circulation pattern strongly resembles the book-end (or line end) vortices that are observed on both sides of a rear-inflow jet of a bow echo (e.g., Weisman 1993), although the clear vortical circulations were seen only below $1 \mathrm{~km}$ in the present case. Weisman (1993) showed that the focusing effect of a vortex couplet further enhances the rear-inflow jet between the vortices.

The cross section at $2 \mathrm{~km}$ indicates a mesoscale 
downdraft on the rear side of the high-reflectivity region, indicating that the rear-inflow jet descended to the ground farther rearward of the convective system's leading edge than at 2218 LST. Note also that rear-inflow notches were sharply defined at $(x, y) \sim(-30 \mathrm{~km}, 38 \mathrm{~km})$ and $(x, y) \sim(-35 \mathrm{~km}$, $33 \mathrm{~km})$. The relative flow patterns at 5.0 and $7.0 \mathrm{~km}$ were qualitatively the same as those at 2218 LST, and the flow patterns still exhibit characteristics of obstacle flow. At this time, strongest updraft was clearly indicated in the northwestern part at $(x, y) \sim(-48 \mathrm{~km}, 52 \mathrm{~km})$ at $5.0 \mathrm{~km} \mathrm{ASL}$, and the prestorm midlevel flows turned around the updraft.

\subsection{Evolution of the rear-inflow jet}

To see the vertical structure and the evolution of the rear-inflow jet, Fig. 13 presents the vertical cross sections across the northern part of the system every 12 minutes from 2154 to 2230 LST. The cross section at 2154 LST indicates a mature convective cell with a maximum reflectivity exceeding $40 \mathrm{dBZ}$, located $\sim 6 \mathrm{~km}$ ASL. At this time, the highreflectivity area was dominated by updrafts. The analyzed maximum updraft magnitude was approximately $8 \mathrm{~m} \mathrm{~s}^{-1}$ at $6 \sim 7 \mathrm{~km}$ ASL. Below the updrafts, an elevated rear-inflow jet, with a maximum ground-relative speed of $\sim 17 \mathrm{~m} \mathrm{~s}^{-1}$, was indicated. The high-reflectivity core then started to descend to the ground. The cross section at 2206 LST indicates the descended core of high reflectivity at $\sim 2 \mathrm{~km}$ ASL and weaker updrafts than those at 2154 LST. An augmentation of the rear-inflow jet in the system was evident, as seen by the appearance of an $18 \mathrm{~m} \mathrm{~s}^{-1}$-contour of horizontal velocity at approximately $2 \mathrm{~km}$ ASL. This indicates that the convective system accelerated the rear-inflow jet. At this time, downward motion was indicated in the leading portion of the rear-inflow jet. At 2218 LST, the rear-inflow jet was more clearly descending to the ground, and the strong horizontal wind exceeding $18 \mathrm{~m} \mathrm{~s}^{-1}$ was analyzed even at the lowest analysis level, at the leading edge of the precipitation area. The rear-inflow jet descended to the ground farther rearward of the convective system's leading edge at 2230 LST, as noted in Fig. 12b. By this time, a new convective cell, which probably initiated at the outflow's leading edge, was apparent at $x \sim-49 \mathrm{~km}$.

The characteristic features of the northern part of the convective system that were revealed by the Doppler radar analysis, including the convex shape of the convective line, the descending enhanced rear-inflow jet positioned at its apex, and mesoscale vortices on both sides of the rear-inflow jet, were strongly reminiscent of bow echoes, which are a well-known mode of severe convection in midlatitude regions that have long been recognized for producing a swath of damaging surface winds (e.g., Fujita 1981; Fujita and Wakimoto 1981; Forbes and Wakimoto 1983). Fujita (1981) hypothesized that a strong descending rear-inflow jet was the source of the damaging winds at the bow apex.

The observation of a bow-shaped tropical mesoscale convective system with a remarkable mesoscale vortex is rare, but Jorgensen et al. (1997) reported the development of counter-rotating vortices and the coincident development of a "bow" in the leading convective line for a tropical squall line observed during the Tropical Ocean Global Atmosphere Coupled Ocean-Atmosphere Response Experiment (TOGA COARE). Note that the squall line investigated by Jorgensen et al. (1997) developed in a rather strong low-level shear environment as in our case, with a $13 \mathrm{~m} \mathrm{~s}^{-1}$ westerly jet maximum located at $800 \mathrm{hPa}$.

\section{Discussion}

In this section, we discuss the factors that might be responsible for the occurrence of the unusual strong wind.

\subsection{Effect of topography}

We noted in Fig. 10 that a pronounced jet exceeding $15 \mathrm{~m} \mathrm{~s}^{-1}$ extended from the relatively low topography area in the mountain range, toward the northern part of the convective system. Figure 14 shows a horizontal cross section as in Fig. $10 \mathrm{f}$ but at $3.0 \mathrm{~km}$ ASL. Although the weak wind region in the downstream region of Mt. Singgalang was still evident, the jet-like feature seen in Fig. 10f was not recognized at this level. Although a convective system may create a rear-inflow jet by itself, this suggests that the effect of topography is important for the easterly jet formation.

When a low-level wind passes through a gap in a mountain barrier or throgh a channel between two mountain ranges, it can develop into a strong wind, referred to as a gap wind, as a result of the acceleration associated with the pressure gradient force across the barrier or along the channel (e.g., Scorer 1952; Overland and Walter 1981; Baines 1995; Steenburgh et al. 1998; Gaberšek and Durran 2004). The easterly jet behind the convective system may be identified as a gap flow because it extended 

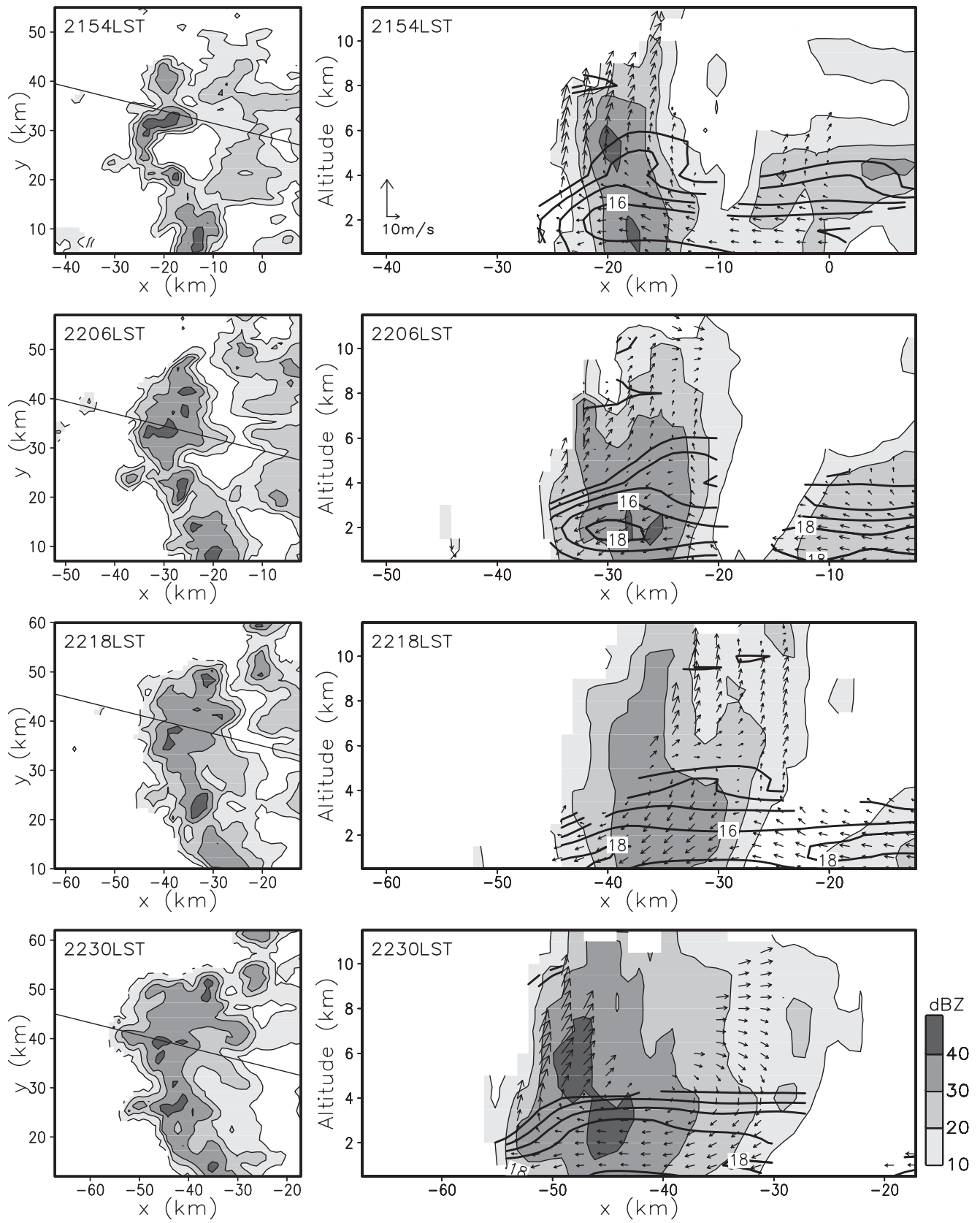

Fig. 13. (left) Horizontal cross sections showing radar reflectivity at $2.0 \mathrm{~km}$ ASL and (right) vertical cross sections showing radar reflectivity and system-relative winds in the plane of the cross section every $12 \mathrm{~min}$ from 2154 to 2230 LST on 19 November, 2006. The solid lines in the horizontal sections represent the locations of vertical cross sections. Ground-relative horizontal wind velocity is contoured in vertical sections at $10,12,14,16$ and $18 \mathrm{~m} \mathrm{~s}^{-1}$. The $10 \mathrm{~m} \mathrm{~s}^{-1}$ scaling vectors for horizontal and vertical winds are shown in the vertical section at 2154 LST.

from the low-topography area in the mountain range and was concentrated at low levels.

The jet appears to contribute to the formation of the bow-echo-like structure in the northern part of the convective system and the formation of lowlevel intense wind. Additionally, the effect of the convective system on the formation of the jet could also be substantial because the convective system 


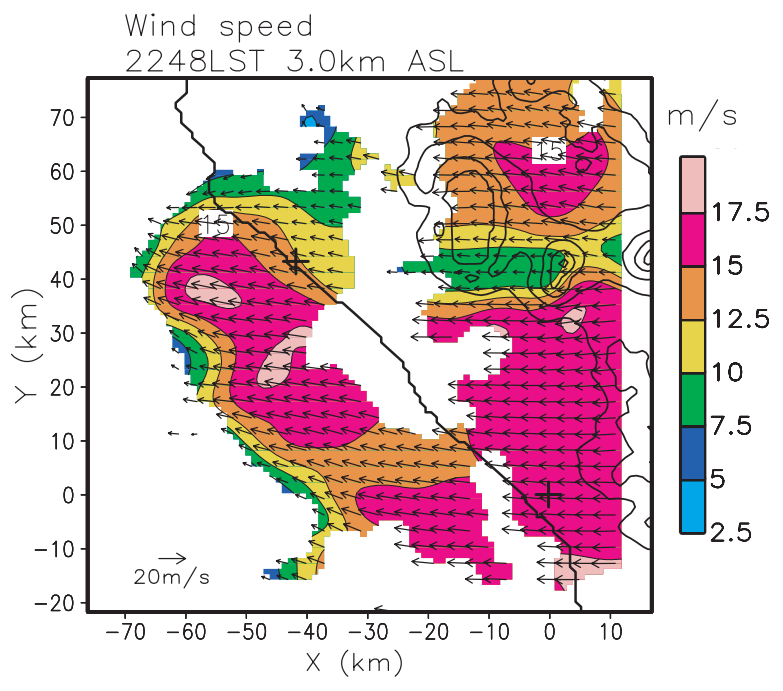

Fig. 14. Horizontal cross section showing ground-relative wind vectors and wind speed at $3.0 \mathrm{~km}$ ASL at $2248 \mathrm{LST}$ on November 19, 2006. The $20 \mathrm{~m} \mathrm{~s}^{-1}$ scaling vectors for winds are shown in the panel, and the velocity scale is shown to the right of the panel. The locations of the Tiku and MIA XDR sites are indicated by crosses.

may hydrostatically reduce the low-level pressure behind it, thereby enhancing the horizontal pressure gradient force across the mountain range. Note that the wind speed in the immediate downstream area of low topography $(x=-20 \sim 5 \mathrm{~km})$ was larger at 2218 LST than at 2248 LST in Fig. 10 . This is probably because the convective system was closer to the low topography area and exerted a stronger pressure gradient force there at 2218 LST than at 2248 LST.

Though not shown, preliminary results of our numerical simulations using version 3.2 of Weather Research and Forecasting (WRF) model confirmed that the presence of a low-topography area in the mountain range was indispensable for the occurrence of intense wind in the present case. While the observed precipitation and wind fields were reproduced successfully in a simulation utilizing a realistic model topography, a pronounced easterly jet behind the convective system was absent and the near surface wind beneath the convective system weakened significantly when the low-topography area was absent in the model topography. In our future study, the mechanism of formation of the intense wind will be examined in detail based on numerical simulations.

\subsection{Equatorial Rossby wave}

We have shown that the convective system developed under an environment of strong low-level easterly vertical shear that is associated with the easterly region of an equatorial Rossby wave. As mentioned in section 3, the easterly wind at $700 \mathrm{hPa}$ over central Sumatera was strongest in this period in 2006. Although the near-surface wind was weak, a convective system that develops in such a largely sheared environment may transport the large easterly momentum in the upper levels to the surface. The presence of the strong easterly wind shear is also favorable for the enhancement of the updrafts at the leading edge of the westward-propagating convective system, because the prestorm, low-level wind shear acts to balance with the baroclinically-generated horizontal vorticity that is associated with the cold pool, leading to the formation of strong convective updraft at the leading edge (e.g., Rotunno et al. 1988). A numerical study by Weisman (1993) indicated that both large amounts of CAPE and strong vertical wind shear are required for the development of severe, long-lived bow echoes. Thus, the easterly phase of the equatorial Rossby wave appeared to build a suitable environment for the development of the convective system that may cause intense surface wind.

\subsection{Dry air intrusion associated with a 5-day- period meridional wind perturbation}

The upper air sounding data immediately following the intense wind event (0100 LST on 20 November, 2006) indicated dry southerly air in the lower troposphere (Fig. 8). Both the radar-derived winds and the poststorm sounding indicated that the wind speed in the dry layer was faster than the movement of the convective system, indicating that the environmental dry air flew across the back edge of the precipitation area of the convective system. It is suggested that the dry air caused stronger evaporative cooling than usual and contributed to the effective downward transport of large southeasterly wind momentum. The presence of well-defined rear-inflow notches, noted in Fig. 12b, might support this assumption.

Frequent appearances of extremely dry air in the lower and mid troposphere over the tropical western Pacific Ocean, first recognized in the TOGA COARE IOP data sets, has received a great deal of attention (e.g., Parsons et al. 1994; Numaguti et al. 1995; Yoneyama and Fujitani 1995; Mapes 
and Zuidema 1996; Johnson et al. 1996; Sheu and Liu 1995; DeMott and Rutledge 1998; Yoneyama and Parsons 1999; Parsons et al. 2000). The formation of the dry layer cannot be explained by vertical adiabatic displacements near the trailing edge of mesoscale convective systems. Instead, the horizontal advection of air from the subtropics has been shown to explain the appearance of the dry air masses (Numaguti et al. 1995; Yoneyama and Fujitani 1995; Mapes and Zuidema 1996; Johnson et al. 1996). Numaguti et al. (1995) showed that 4-5-dayperiod mixed Rossby-gravity (MRG) waves played an important role in the advection of dry air in the two cases of dry events observed during TOGA COARE.

The dry air event noted in Fig. 4 resembles the case analyzed by Numaguti et al. (1995), in that the dry air appeared associated with the $\sim 5$-dayperiod meridional wind variation. To investigate the large-scale structure responsible for the 5-dayperiod variation in the wind and humidity, the NCEP/NCAR global objective analysis data in the observation period was examined. Though not shown for brevity, the characteristic variations captured by radiosoundings at Tabing, including the $\sim 5$-day-period variation of meridional wind and the appearance of lower-tropospheric dry air, were also found at the nearest grid point of the reanalysis data. However, the dry layer was somewhat moister, and the increase in the level of the dry layer with time was not clearly represented in the reanalysis data.

Figure 15 shows the longitude-time section of zonal and meridional winds and relative humidity at the equator and zonal wind at $7.5^{\circ} \mathrm{S}$ at $600 \mathrm{hPa}$. Note that a 1-day running mean was applied for each variable, to dampen significant diurnal variations of the variables. A westward propagating signal of an equatorial Rossby wave is clearly seen in the zonal wind fields at the equator (Fig. 15a). On the other hand, the section for meridional wind indicates a $~ 5$-day-period signal from November $17-$ 25 around $100^{\circ} \mathrm{E}$ that also propagated westward (Fig. 15b). The phase speed was approximately $22 \mathrm{~m} \mathrm{~s}^{-1}$ around $100^{\circ} \mathrm{E}$, much faster than the easterly wind speed there. Associated with the southerly wind phase around $100^{\circ} \mathrm{E}$ on November $20-21$, westward extension of the relatively dry region with humidity below $60 \%$ was observed (Fig. 15c).

Although the 5-day-period westward propagating signal was not clearly seen in the zonal wind field at the equator, the section at $7.5^{\circ} \mathrm{S}$ (Fig. 15d) clearly shows the 5-day-period signal. These results suggest that the 5-day-period signal would be associated with an MRG wave, because for an MRG wave, perturbation fields other than that for meridional wind are asymmetric with respect to the equator (e.g., Matsuno 1966). Note also that the phase of the zonal wind perturbation at $7.5^{\circ} \mathrm{S}$ was about $90^{\circ}$ in front of that of the meridional wind speed at the equator, which is also consistent with the phase relationship for an MRG wave.

It should also be noted that the augmentation of the amplitude of the 5-day-period signal was seen in the longitudinal range between 90 and $110^{\circ} \mathrm{E}$. A time-longitude section of $T_{B B}$ (not shown) also indicates a westward-propagating signal of low- $T_{B B}$ extending over the longitudinal range between 90 and $110^{\circ} \mathrm{E}$ for the periods of November $19-20$ and November 24-25. These results suggest that the wave became coupled with convective activity over the IMC.

\section{Summary and conclusions}

In this study, processes responsible for an intense wind event that occurred in west Sumatera on November 19, 2006, during the HARIMAU2006 campaign were investigated. Strong winds of $17 \mathrm{~m} \mathrm{~s}^{-1}$ and a sudden temperature drop of $5 \mathrm{~K}$ were observed at an XDR site on that day associated with the passage of a band-shaped convective system. Some houses around the XDR site were severely damaged by the strong wind.

The convective system developed under an environment of strong low-level easterly vertical shear that was associated with an equatorial Rossby wave. The convective system exhibited significant north-south asymmetry with an enhanced rearinflow jet located in its northern part. The characteristic features of the northern part of the convective system, including the convex shape of the convective line, the descending rear-inflow jet positioned at its apex, and the mesoscale vortices on both sides of the rear-inflow jet, were qualitatively similar to those associated with a bow echo, which is a well-known mode of severe convection that produces a swath of damaging surface winds in midlatitude regions.

The analysis of the Doppler radar data revealed that low-level (below $\sim 2 \mathrm{~km} \mathrm{ASL}$ ) wind behind the convective system formed a channel of strong easterly wind exceeding $15 \mathrm{~m} \mathrm{~s}^{-1}$ as it passed through an area of relatively low topography in 
(a) Zonal wind $600 \mathrm{hPa}$ lat $=0$

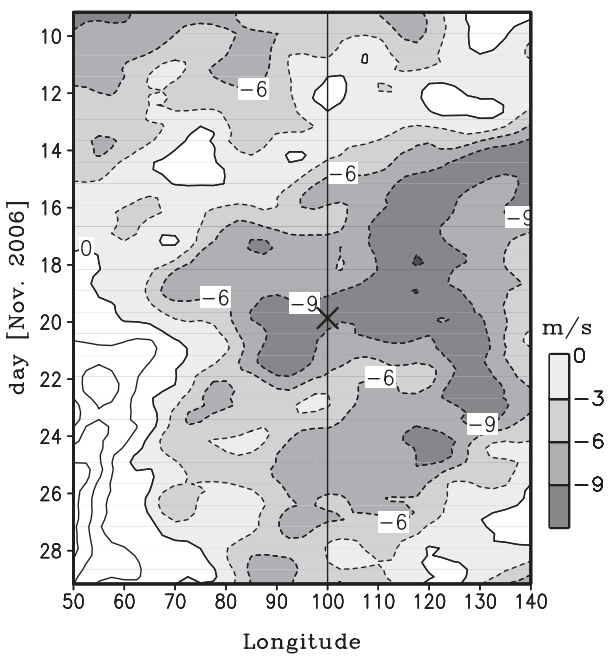

(c) Relative humidity $600 \mathrm{hPa}$ lat $=0$

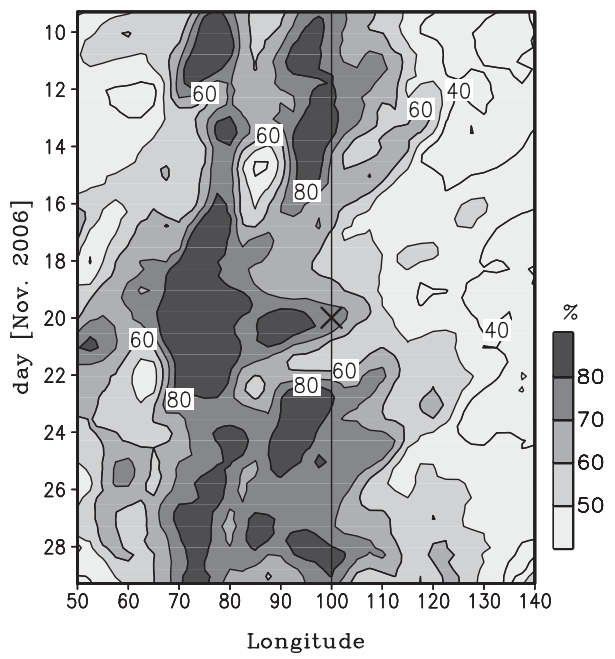

(b) Meridional wind $600 \mathrm{hPa}$ lat $=0$

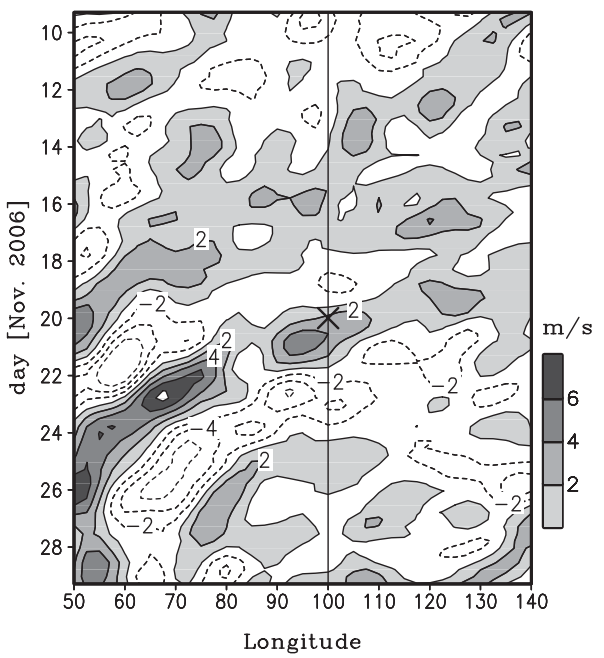

(d) Zonal wind $600 \mathrm{hPa}$ lat $=7.5 \mathrm{~S}$

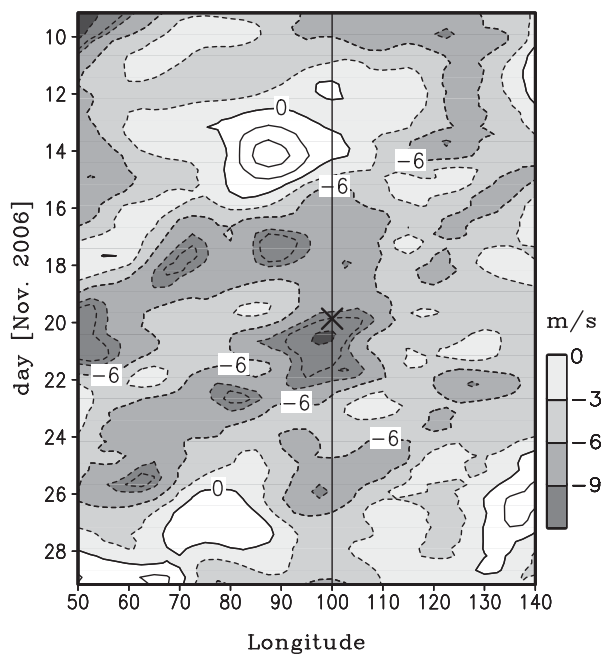

Fig. 15. Time-longitude plots at $600 \mathrm{hPa}$ of (a) zonal wind at the equator $\left(3 \mathrm{~m} \mathrm{~s}^{-1}\right.$ contour interval) (b) meridional wind at the equator $\left(2 \mathrm{~m} \mathrm{~s}^{-1}\right.$ contour interval), (c) relative humidity at the equator $(10 \%$ contour interval), and (d) zonal wind at $7.5^{\circ} \mathrm{S}\left(3 \mathrm{~m} \mathrm{~s}^{-1}\right.$ contour interval). The time and location of the intense wind event at Tiku (2215 LST on November 19, 2006) is marked by a cross.

the mountain range. The enhanced easterly wind is thought to contribute to the formation of a bow echo-like structure in the northern part of the convective system. This easterly rear-inflow jet was further accelerated in the convective system and descended near the leading edge, forming divergent strong winds at the surface.

The upper air sounding data that were taken after the passage of the convective system indicated that dry air appeared in the lower troposphere associated with an enhancement of the southerly wind component. An analysis of objective reanalysis data suggests that the southerly was probably associated with a westward-propagating MRG wave with a period of approximately 5 days. It is suggested that the dry air intruded into the convective system across the back edge of the precipitation area and caused enhanced evaporation cooling, which probably resulted in the effective downward transport of the enhanced easterly momentum.

We have argued that the unusual damaging surface winds occurred as a result of the interplay of topography and atmospheric disturbances of very different scales, equatorial waves and diurnal con- 
vections. The results of this study also highlight the need for monitoring both large-scale and smallscale disturbances with high temporal and spatial resolutions to prevent disasters caused by intense winds over the IMC.

\section{Acknowledgements}

The HARIMAU project is supported mainly by the Japan EOS Promotion Program (JEPP) of the Ministry of Education, Culture, Sports, Science and Technology (MEXT) of Japan, and in part by a Special Grant for High-Level Science, Technology and Research of the Government of the Republic of Indonesia. We would also like to thank Dr. Yoshinori Yamada for providing Doppler analysis programs and useful comments regarding the analysis of radar data. Thanks are also extended to two anonymous reviewers for their helpful comments.

\section{References}

Baines, P. G., 1995: Topographic Effects in Stratified Flows. Cambridge University Press, 496 pp.

Bousquet, O., and M. Chong, 1998: A multiple-Doppler synthesis and continuity adjustment technique (MUSCAT) to recover wind components from Doppler radar measurements. J. Atmos. Oceanic Technol., 15, 343-359.

Chong, M., and S. Cosma, 2000: A formulation of the continuity equation of MUSCAT for either flat or complex terrain. J. Atmos. Oceanic Technol., 17, 1556-1564.

Chong, M., and J. Testud, 1983: Three-dimensional wind field analysis from dual-Doppler radar data. part III: The boundary condition: An optimum determination based on a variational concept. J. Climate Appl. Meteor., 22, 1227-1241.

DeMott, C. A., and S. A. Rutledge, 1998: The vertical structure of TOGA COARE convection: Part II: Modulating influences and implications for diabatic heating. J. Atmos. Sci., 55, 2748-2762.

Forbes, G. S., and R. M. Wakimoto, 1983: A concentrated outbreak of tornadoes, downbursts and microbursts, and implications regarding vortex classification. Mon. Wea. Rev., 111, 220-236.

Fujita, T. T., 1981: Tornadoes and downbursts in the context of generalized planetary scales. J. Atmos. Sci., 38, 1511-1534.

Fujita, T. T., and R. M. Wakimoto, 1981: Five scales of airflow associated with a series of downbursts of 16 July 1980. Mon. Wea. Rev., 109, 1438-1456.

Gaberšek, S., and D. R. Durran, 2004: Gap flows through idealized topography. Part I: Forcing by large-scale winds in the nonrotating limit. J. Atmos. Sci., 61, 2846-2862.
Johnson, R. H., P. E. Ciesielsk, and K. A. Hart, 1996: Tropical inversions near the $0^{\circ} \mathrm{C}$ level. J. Atmos. Sci., 53, 1838-1855.

Jorgensen, D. P., M. A. LeMone, and S. B. Trier, 1997: Structure and evolution of the 22 February 1993 TOGA COARE squall line: Aircraft observations of precipitation, circulation, and surface energy fluxes. J. Atmos. Sci., 54, 1961-1985.

Kawashima, M., Y. Fujiyoshi, M. Ohi, T. Honda, T. Kozu, T. Shimomai, and H. Hashiguchi, 2006: Overview of Doppler radar observations of precipitating cloud systems in Sumatera Island during the first CPEA campaign. J. Meteor. Soc. Japan, 84A, 33-56.

Kiladis, G. N., G. A. Meehl, and K. M. Weickmann, 1994: Large-scale circulation associated with westerly wind bursts and deep convection over the western equatorial Pacific. J. Geophys. Res., 99, $18527-18544$.

Lin, X., and R. H. Johnson, 1996: Kinematic and thermodynamic characteristics of the flow over the western Pacific warm pool during TOGACOARE. J. Atmos. Set., 53, 695-715.

Mapes, B. E., and P. Zuidema, 1996: Radiativedynamical consequences of dry tongues in the tropical troposphere. J. Atmos. Sci., 53, 620-638.

Matsuno, T., 1966: Quasi-geostrophic motions in the equatorial area. J. Meteor. Soc. Japan, 44, 25-43.

Miura, H., M. Satoh, and M. Katsumata, 2009: Spontaneous onset of a Madden-Julian oscillation event in a cloud-system-resolving simulation. Geophys. Res. Lett., 36, L13802, doi:10.1029/ 2009 GL039056.

Mori, S., J.-I. Hamada, Y. I. Tauhid, M. D. Yamanaka, N. Okamoto, F. Murata, N. Sakurai, and T. Sribimawati, 2004: Diurnal land-sea rainfall peak migration over Sumatera Island, Indonesia maritime continent observed by TRMM satellite and intensive rawinsonde soundings. Mon. Wea. Rev., 132, 2021-2039.

Mori, S., J.-I. Hamada, N. Sakurai, H. Fudeyasu, M. Kawashima, H. Hashiguchi, F. Syamsudin, A. A. Arbain, R. Sulistyowati, J. Matsumoto, and M. D. Yamanaka, 2011: Convective systems developed along the coastline of Sumatera Island, observed with an X-band Doppler radar during the HARIMAU2006 campaign. J. Meteor. Soc. Japan, 89A, 61-81.

Murakami, T., and W. L. Sumathipala, 1989: Westerly bursts during 1982/83 ENSO. J. Climate, 2, 71-85.

Murata, F., M. D. Yamanaka, H. Hashiguchi, S. Mori, M. Kudsy, T. Sribimawati, B. Suhardi, and Emrizal, 2006: Dry intrusions following eastwardpropagating synoptic-scale cloud systems over Sumatera Island. J. Meteor. Soc. Japan, 84, 277294.

Nitta, T., and T. Motoki, 1987: Abrupt enhancement 
of convective activity and low-level westerly wind burst during the onset phase of 1986-87 El Niño. J. Meteor. Soc. Japan, 65, 497-506.

Numaguti, A., R. Oki, K. Nakamura, K. Tsuboki, N. Misawa, T. Asai, and Y. Kodama, 1995: 4-5-dayperiod variation and low-level dry air observed in the equatorial western Pacific during the TOGACOARE IOP. J. Meteor. Soc. Japan, 73, 267-290.

Parsons, D., K. Yoneyama, and K. L. Redelsperger, 2000: The evolution of the tropical western Pacific atmosphere-ocean system following the arrival of a dry intrusion. Quart. J. Roy. Meteor. Soc., 126, 517-548.

Parsons, D., W. Dabberdt, H. Cole, T. Hock, C. Martin, A.-L. Barrett, E. Miller, M. Spowart, M. Howard, W. Ecklund, D. Carter, K. Gage, and J. Wilson, 1994: The Integrated Sounding System: Description and preliminary observations from TOGA COARE. Bull. Amer. Meteor. Soc, 75, 553-567.

Przybylinski, R. W., 1995: The bow echo: Observations, numerical simulations, and severe weather detection methods. Wea. Forecasting, 10, 203-218.

Ramage, C. S., 1968: Role of a tropical 'maritime continent' in the atmospheric circulation. Mon. Wea. Rev., 96, 365-369.

Rotunno, R., J. B. Klemp, and M. L. Weisman, 1988: A theory for strong, long-lived squall lines. J. Atmos. Sci., 45, 463-485.

Sakurai, N., F. Murata, M. D. Yamanaka, S. Mori, J.-I. Hamada, H. Hashiguchi, Y. I. Tauhid, T. Sribimawati, and B. Suhardi, 2005: Diurnal cycle of cloud system migration over Sumatera Island. J. Meteor. Soc. Japan, 83, 835-850.

Scorer, R., 1952: Mountain-gap winds; a study of surface wind at Gibraltar. Quart. J. Roy. Meteor. Soc., 78, 53-61.

Seto, T. H., M. K. Yamamoto, H. Hashiguchi, and S. Fukao, 2004: Convective activities associated with intraseasonal variation over Sumatera, Indonesia observed with the equatorial atmospheric radar. Ann. Geophys, 22, 3899-3916.

Seto, T. H., M. K. Yamamoto, H. Hashiguchi, S. Fukao, M. Abo, T. Kozu, and M. Kudsy, 2006: Observational study on westerly wind burst over Sumatera, Indonesia by the equatorial atmospheric radar-a case study during the first CPEA campaign-. $J$. Meteor. Soc. Japan, 84A, 95-112.

Sheu, R. S., and G. Liu, 1995: Atmospheric humidity variations associated with westerly wind bursts during Tropical Ocean Global Atmosphere
(TOGA) Coupled Ocean Atmosphere Response Experiment (COARE). J. Geophys. Res., 100, 25 759-25768.

Smull, B. F., and R. A. Houze, Jr., 1985: A midlatitude squall line with a trailing region of stratiform rain: Radar and satellite observations. Mon. Wea. Rev., 113, 117-133.

Smull, B. F., and R. A. Houze, Jr., 1987: Rear-inflow in squall lines with trailing stratiform precipitation. Mon. Wea. Rev., 115, 2869-2889.

Steenburgh, W. J., D. M. Schults, and B. Colle, 1998: The structure and evolution of gap outflow over the Gulf of Teguantepec, Mexico. Mon. Wea. Rev., 126, 2673-2691.

Weisman, M. L., 1993: The genesis of severe, long-lived bow echoes. J. Atmos. Sci., 50, 645-670.

Wyrtki, K., 1975: El Niño-the dynamic response of the equatorial Pacific Ocean to atmospheric forcing. $J$. Phys. Oceanogr., 5, 572-5834.

Yamada, Y., and M. Chong, 1999: VAD-based determination of the Nyquist interval number of Doppler velocity aliasing without wind information. $J . \mathrm{Me}$ teor. Soc. Japan, 77, 444-457.

Yamanaka, M. D., H. Hashiguchi, S. Mori, P.-M. Wu, F. Syamsudin, T. Manik, J.-I. Hamada, M. K. Yamamoto, M. Kawashima, Y. Fujiyoshi, N. Sakurai, M. Ohi, R. Shirooka, M. Katsumata, Y. Shibagaki, T. Shimomai, Erlansyah, W. Setiawan, B. Tejasukmana, Y. S. Djajadihardja, and J. T. Anggadiredja, 2008: HARIMAU radar-profiler network over the Indonesian maritime continent: A GEOSS early achievement for hydrological cycle and disaster prevention. J. Dis. Res., 3, 78-88.

Yoneyama, K., and T. Fujitani, 1995: The behavior of the dry westerly air associated with convection observed during TOGA coare R/V Natsushima Cruise. J. Meteor. Soc. Japan, 73, 291-304.

Yoneyama, K., and D. P. Parsons, 1999: A proposed mechanism for the intrusion of dry air into the tropical western Pacific region. J. Atmos. Sci., 56, 1524-1546.

Yoneyama, K., Y. Masumoto, Y. Kuroda, M. Katsumata, K. Mizuno, Y. N. Takayabu, M. Yoshizaki, A. Shareef, Y. Fujiyoshi, M. J. McPhaden, V. S. N. Murty, R. Shirooka, K. Yasunaga, H. Yamada, N. Sato, T. Ushiyama, Q. Moteki, A. Seiki, M. Fujito, K. Ando, H. Hase, I. Ueki, T. Horii, C. Yokoyama, and T. Miyakawa, 2008: MISMO field experiment in the equatorial Indian Ocean. Bull. Amer. Meteor. Soc., 89, 1889-1903. 